This is an electronic version of an Article published in The Russian review. 58, 1, 87. (January 01, 1999). 


\section{The Return to Nature: Tolstoyan Echoes in The Idiot}

\section{DONNA ORWIN}

$\mathrm{C}$ ritics have long noted the presence of Tolstoy in The Idiot. The editors of the Academy edition of the novel comment on this, and Robin Feuer Miller extends their remarks in her seminal Dostoevsky and The Idiot: Author, Narrator; and Reader.' Collating these earlier Tolstoy sightings in The Idiot and adding some of my own, I will try to make sense of them as pieces of a coherent pattern of response to Tolstoy. In some cases I will argue that Dostoevsky is deliberately engaging Tolstoy or quoting him. In others, Dostoevsky's text cries out for comparison with Tolstoy, whether or not comparison was intended. The reason for this is that The Idiot grew out of concerns that preoccupied both writers.

In The Idiot Tolstoy and Dostoevsky clearly meet at the level of "idea." Miller discusses the distinction for Dostoevsky between the idea of a work, which preceded everything else, and its realization in narrative form. The plans in Dostoevsky's notebooks for The Idiot, as for later novels, are "various sets of narrative strategies" aimed at realizing an idea. ${ }^{2}$ Miller stresses that Dostoevsky is not a thinker who straightforwardly reasons with his reader, but a "novelist of ideas," for whom "the narration should be the only link

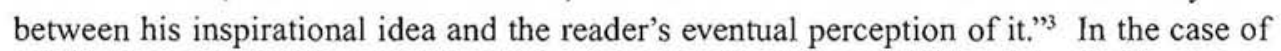
The Idiot, what Miller calls its "inspirational idea" became connected in Dostoevsky's own mind with Tolstoy. Dostoevsky seems to have thought of Tolstoy only after he had decided, in late fall 1867 , that his novel would be a portrait of a truly good man. Recognizing this moment of convergence, he acknowledged it by naming his hero Lev Nikolaevich. He thereby drew an unmistakable connection between Prince Myshkin and Lev Nikolaevich Tolstoy. ${ }^{4}$

'F. M. Dostoevskii, Polnoe sobranie sochinenï i pisem, 30 vols. (Leningrad, 1972-88), 9:364-65, 452-53, 465. All references in the text and notes to Dostoevsky are by volume and page number to this Academy edition. All translations are my own. See also Robin Feuer Miller, Dosloevsky and The Idiot: Aulhor, Narralor; and Reader (Cambridge, MA, 1981), 59-60.

${ }^{2}$ Miller, Dosloevsky and The Idiot, 38.

${ }^{3}$ Ibid., 45.

'This happened sometime before January 1868 , probably in December, just beforc Dostoevsky sent off the first installment of The Idiol. I do not mean to suggest that Myshkin is Tolstoy. Rather, as Irene Masing-Delic put it to $m e$ in a private communication concerning this essay, the prince is a Dostoevskian fictional character who shares certain ideas with Tolstoy. I would like to thank Professor Masing-Delic, my anonymous reader, and Robin Miller for their heipful comments. 
In Notes from the House of the Dead (1860), the most Tolstoyan of all Dostoevsky's works - and the one most beloved by Tolstoy-nature and the natural cycle had been contrasted with the distorted life of the Siberian prison camp, itself a mirror of Russian society. ${ }^{5}$ Both Tolstoy and Dostoevsky experienced nature as a source of pure joy; for Dostoevsky, however, a return to nature as a moral standard was problematic, and nature itself posed a threat to morality. Having pushed the theme of human freedom farther than ever before in Notes from the Underground (1864), he began to focus on the need for a morality, or, as he called it, an ideal, that would preserve goodness without compromising freedom. ${ }^{6}$ In The Idiot Dostoevsky is working out his own position on the relation between nature and morality. Wandering through Switzerland and the park at Pavlovsk with his hero Myshkin, he crosses paths with his great Rousseauian contemporary and rival Tolstoy.

\section{LEV NIKOLAEVICH MYSHKIN AND CHILDHOOD}

When Dostoevsky named his hero after Tolstoy, War and Peace was still unfinished. Dostoevsky would have been acquainted only with the parts of the novel-then entitled 1805-that had come out in 1865 and 1866, which he had read while he was writing Crime and Punishment. I agree with D. L. Sorokina that in naming Myshkin Lev Nikolaevich, Dostoevsky was probably thinking primarily of Tolstoy as the founder of the school at Iasnaia Poliana, and the editor and writer of the pedagogical journal of that name.? During his first visit to the Epanchins in part 1, Myshkin recalls how he told the Swiss village teacher Thibaud that the children should be teaching Thibaud and himself rather than the other way around, "that neither of us will teach them anything, but it will be they who teach us" (chto my oba ikh nichemu ne nauchim, a oni eshche nas nauchat, 8:58). Myshkin subscribes here to a key tenet of the pedagogy that Tolstoy defended in articles certainly known to Dostoevsky. ${ }^{8}$

\footnotetext{
${ }^{3}$ Robert Louis Jackson discusses the positive and structuring role of nature and the seasous in Notes from the House of the Dead. See his The Art of Dostoevsky: Deliriums and Nocturnes (Princeton, 1981), 40-41. The resultant circular structure of the work, also remarked on by Jackson, is a feature that it shares with War and Peace. Even in this most Tolstoyan of his works, however, Dostoevsky is more Christian than the early Tolstoy in his emphasis.

'In this general interpretation of Noles from the Underground I follow Jackson, The Arl of Dosloevshy, Joseph Frank, Dostoevsky: The Stir of Liberation, 1860-1865 (Princeton, 1986), 310-45; and Liza Knapp, The Annihilafion of Inerria: Dostoevsky and Melaphysics (Evanston, 1996), 21-29.

'The editors of the Academy edition, citing Sorokina, "Zamysel i ego osushchestvlenie," Uchenye zapishi Tomskogo universitela, no. 50, 1965, connect Myshkin with Tolstoy's teaching methods at the Iasnaia Poliana school (9:364). The editors also point out that, while extensive plans in the drafts for a children's school and club are not realized in the novel, there are sympathetic children through the book, and many adult heroes (Nastasia Filippovna, Aglaia, Madame Epanchina, Keller, Ippolit, Gania) have, as Myshkin understands them, a childlike purity of heart (9:365). Myshkin himself, of course, is childlike, so much so that early on, when General Epanchin learns that Myshkin is twenty-six, he exclaims that he would have thought him much younger $(8: 24)$. Various contemporary critics commented on Myshkin's resemblance to a child (9:413-41).

${ }^{8} \mathrm{~V}$ remia, the journal founded and edited by Dostocvsky and his brother Mikhail, followed Tolstoy's pedagogical essays in Jasnaia Poliana and commented on them sympathetically. See Frank, Dostoevshy: The Stir of Liberation, 102.
} 
These lines allude not only to Tolstoy's teaching methods but specifically to his article "Who Should Be Teaching Whom to Write: Should We Be Teaching the Peasant Lads, or They Us?" (Komu u kogo uchitsia pisat', krest 'ianskim rebiatam u nas, ili nam u krest'ianskikh rebiat?) Here Tolstoy rises to a crescendo with a crucial declaration of principle that may have helped to crystallize Dostoevsky's understanding of the relation between himself and Tolstoy.

Man is born perfect - this is the great word uttered by Rousseau, and this word, like a rock, remains hard and true. Just born, man is the very image of the harmony of the true, the beautiful, and the good. But every hour of life, every minute of time expands the spaces, the quantities, and the time of these relations, which at the time of his birth were in perfect harmony, and every step and every hour threatens the destruction of this harmony, and every successive step and every successive hour threatens new destruction and does not hold out hope for the restoration of destroyed harmony. ... Our ideal is behind, and not ahead of $u s^{9}$

Children have something to teach us because they are closer to original perfection. Tolstoy and Dostoevsky share a common belief in the natural goodness of children. In Tolstoy's view, this "natural goodness" grows out of the "two best virtues" of childhood: "innocent merriment and a limitless need for love."10 The first stems from physical, the second, from spiritual vitality. Neither requires Christian self-sacrifice or even conscious moderation, neither of which is ever practiced by children in Tolstoy's works. For Tolstoy, happiness, not goodness, is the natural goal of children, but in children at least happiness and goodness can coincide. Children are happy when their desires do not exceed their powers, and they are good because it is overweening desires that create evil. They are naturally loving both because they themselves are loved, and because they do not depend for their happiness on the subjugation of other people. Myshkin concurs with this view: the Swiss children as he depicts them to the Epanchins behave like children from Tolstoy's Childhood, as described in the central chapter of the same name. They rush along on waves of feeling, passing from tears to laughter, from one emotion to another, fighting and making up without holding grudges. They are benevolent but not self-sacrificing. They interpret Myshkin's kindness to Marie as proof that he is "in love" with her because they have seen passionate love in their elders, but the kind of passionate pity that Myshkin feels for Marie is beyond their ken. As in Tolstoy, their childish innocence and lack of vice, rather than any positive virtue, defines their goodness.

Dostoevsky agreed that this is true for normal healthy children like those in the Swiss village. At the same time, though, while accepting the natural goodness of children in this sense, and their stronger link to perfection by virtue of it, he thought that their corruption was inevitable because it is itself the result of natural forces, and especially the development of the passions. In "Who Should Be Teaching Whom?" by contrast, Tolstoy blames

${ }^{9} \mathrm{~L}$. N. Tolstoi, Polnoe sobranie sochinenii (PSS), 90 vols. (Moscow, 1928-58), 8:321-22. All references to Tolstoy in the text and notes are to volume and page of this Jubilee edition of Tolstoy's works. All translations of Tolstoy are my own.

"Tolstoi, "Detstvo" (Childhood), PSS 1:chap. 15 ("Detstvo"). 
others, and specifically civilization, for this corruption: he specifically warns teachers to beware of spoiling the natural harmony and goodness of children. Even he, however, warns that time and action by themselves "threaten" harmony and do "not hold out hope for the restoration of destroyed harmony." He does not specify in his ringing declaration whether the dangers are natural or artificial. Childhood is more realistic than anything in Russian literature written before it (including previous works by Dostoevsky) in its depiction both of childish sexuality and pride and of the onslaught of adolescence; while Adolescence portrays that stage of life in full passionate flower without much indication that it could have been otherwise. Tolstoy's psychological realism, which made these two books favorite reading for Dostoevsky throughout his life, revealed that vices were intractable, and developed, if in relatively benign form, early."

Given the limits of natural goodness as Dostoevsky understood them, it is not surprising that in The Idiot an unhealthy and unhappy adolescent, the dying Ippolit, is drawn to the green trees of Pavlovsk not in search of virtue, but from a natural desire for happiness (8:246). He comes not to give love, but to find it. Myshkin recognizes himself in Ippolit's confession; he, too, was isolated and outside of life before he made the acquaintance of the children in Switzerland. The identification is so strong that Myshkin feels that in part of Ippolit's "Urgent Explanation" he has articulated Myshkin's own (unspoken) words and feelings from that time (8:352). In Switzerland Myshkin rejoined life (and nature) simply by giving in to the "extremely strong and happy sensation" that he felt when he met the Swiss village children (8:63). Identifying with the children as they rushed along, Myshkin was able to share in their simple natural feelings and felt his own love of life resurrected. ${ }^{12}$

Again, Dostoevsky associates his own psychological realism with Tolstoy. In a conversation with Aglaia on the green bench, Myshkin explains Ippolit's confession and botched suicide as an attempt, grounded in nature, to get others, especially Aglaia, to love him. Aglaia at first objects, but then says

I guess I do understand. You know, I myself, even as far back as when I was a thirteen-year-old girl, around thirty times thought of poisoning myself, and of writing it all in a letter to my parents, and I also thought of how I would lie in the

\footnotetext{
"In 1855, still in exile in Sibcria, Dostoevsky read Adolescence in the journal Sovremennik and was sufficiently struck by it to ask a correspondent the name of its pseudonymous author (28.1:184). Half a year later he praises "L. T." (Tolstoy) in a letter to his literary correspondeut A. N. Maikov (28.1:210). In The Injured and the Insulted [Unizhennye i oskorblennye; 1861], one of the characters recommends Childhood and Adolescence to others. The Adolescent [Podrostok; 1875] is among other things Dostoevsky's response to Tolstoy's gentry accounts of childhood and adolescence; and Dostoevsky explicitly mentions these accounts again in the 1877 Diary of a Writer (25:52).

${ }^{12}$ According to Kennoske Nakamura, Chuvstvo zhizni i smerti u Dostoevskogo (St. Petersburg, 1997), the other, dark side of Dostoevsky's response to nature arises from fear of death, which bars the dying Ippolit from the joy he seeks. Ippolit's reaction to the same scenes, and perhaps even to the same "sensation," might bave been hatred that he was excluded from the "feast of life." It is crucial, of course, that lppolit is dying while Myshkin was recovering from a serious illness when he met the Swiss children. Nakamura distinguishes two different reactions to nature that Dostoevsky felt himself and that he expressed and explored in his fiction: the first is ecstatic joy of life; the second, visceral fear of death. Compare also Andrei's reaction in War and Peace to the children stealing apples in the orchard before the battle of Smolensk.
} 
grave, and everyone would cry over me and blame themselves that they had been so cruel to me.

Aglaia then chastises the prince for smiling at her confession.

"Why are you smiling again," she added quickly, frowning. "Don't you think something about yourself too, when you're daydreaming alone? Maybe you imagine yourself as a field marshal defeating Napoleon?"

"Well to tell the honest truth, I do think about that, especially when I'm falling asleep," the prince laughed, "only I don't defeat Napoleon, but all the Austrians." (8:354)

These musings of Aglaia and Myshkin recall the disturbed dreams of Nikolenka Irteniev in Adolescence. In chapter 15 of that book ("Daydreams"), the merry boy from the corresponding chapter 15 ("Childhood") of Childhood has turned into a teenager who wants to expand to the limits of his powers by conquering even Napoleon, and he wants to gain the love of others through glory. When rejected by others, he takes revenge by imagining his own funeral and the repentance of his tormentors. These are the thoughts that, as the editors of the Academy edition observe, resonate in the conversation on the green bench (9:452-53). Dostoevsky recognized that in Adolescence Tolstoy was writing about the universal expansion of desire, and especially the desire, whether natural or artificially inflamed by civilization, that others love and respect us as much as we do ourselves. So too in The Idiot. not only Ippolit, with his fatal tuberculosis and his low social status, not only the orphaned epileptic Myshkin, but the adored and coddled Aglaia, with every social and personal advantage, in adolescence has felt the torments-real or imagined--of not being loved enough.

The challenge for both Tolstoy and Dostoevsky, then, is not to preserve the natural harmony of childhood and the morality associated with it - for that is impossible - but to replace it with something appropriate for adults. At the beginning of The Idiot, Prince Myshkin has come to Russia to preach the original and childlike "harmony of the true, the beautiful, and the good." Dostoevsky, too, believed in this natural harmony as an ideal embodied in Myshkin. (He recreated it lovingly years later in his Dream of a Ridiculous Man.) In the course of the novel, however, "Russian reality" defeats Myshkin's "Swiss," "Rousseauian" logic, with its belief in "the triumph of virtue." 13 The Rousseauian theme discerned and explicated by Arpad Kovacs is directly linked to Tolstoy through Dostoevsky's reference in the novel to "Who Should Be Teaching Whom To Write?" Tolstoy, like Rousseau - and quoting Rousseau in his essay - calls for a return to natural harmony. In an unspoiled world, nature, in the form of conscience in human beings and necessity in the external world, can keep naturally expansive vitality and self-love in check even in adults. For Dostoevsky, by contrast, nature is the source of innocent vitality, of self-love and the need for happiness, but not of adult morality per se. Neither knowledge of natural necessity nor conscience in its natural state can control vitality in human beings. This

\footnotetext{
${ }^{13}$ Arpad Kovacs, "The Poetics of The Idior. On the Problem of Dostocvsky's Thinking about Genre," in Critical Essays on Dostoevsk, ed. Robin Feuer Miller (Boston, 1986), 119-22.
} 
failure of natural love and moderation to harness passion and curb vice scuttles the plans of Lev Nikolaevich Tolstoy-Myshkin to reform his friends and eventually all Russia. Dostoevsky's position on this issue is worked out in the novel in what may be a hidden polemic with Tolstoy.

\section{LUCERNE}

Prince Myshkin's first name and patronymic are an open and deliberate allusion to Tolstoy. So is the quotation of the name of Tolstoy's pedagogical essay. There are other, less obvious and perhaps not even deliberate Tolstoyan echoes in the Swiss part of the novel. Robin Miller points out that Myshkin, like Pierre Bezukhov, has just returned from Switzerland as the novel opens, and that diary debate over whether Myshkin will be a legitimate or an illegitimate son may reflect the influence of War and Peace. ${ }^{14}$ The critic Orest Miller in a lecture published in 1878 compared Myshkin's befriending of Marie in The Ldiot with Nekhliudov's defense of the itinerant musician in Lucerne (9:417). This mention of Lucerne, whether or not Dostoevsky had it in mind, is suggestive. The editors of the Academy edition see a similarity between Dostoevsky's Winter Notes on Summer Impressions (1863), about his first trip abroad, and Lucerne, published in 1857 after Tolstoy's own first trip to Europe $(5: 358)$. The two differ in one respect crucial to the present discussion. Whereas Tolstoy contrasted the cold and individualistic ways of the English whom he encountered in Geneva with harmony and cooperation within nature, Dostoevsky, just as critical as Tolstoy of the bourgeois individualism that he found in Europe, located cooperation, or the principle of love, in Russian culture. In one passage in part 1 of The Ldiot, he seems to take issue with Luceme over the influence of nature. When the hero of Tolstoy's story, Prince Nekhliudov, first laid eyes on the natural beauty of the town, it "blinded and shook" him: "I felt an inner agitation (bespokoistvo) and the need to somehow express an excess of something suddenly overfilling my soul. At this moment I wanted to embrace someone, to embrace him tightly, to tickle, to pinch him, in general to do something unusual with him and with myself" (5:4).

Nekhliudov's agitation fuels social instincts lacking in the British tourists he observes. Myshkin tells a different story of his arrival in Lucerne. He went boating, and felt both "good and uneasy" (khorosho i bespokoino) at the same time (8:50). He later settled down to a quiet life in a village. Aleksandra asks him if he was never restless. Yes, he replies, "I would fall into periods of great restlessness." Waterfalls made him feel that way, as did walks in the mountains above the village near a ruined castle.

There it would be that everything would summon me somewhere, and it would always seem to me that if I kept going straight, and went on and on and went beyond that line, the one where the sky meets the earth, then the whole solution would be there, and right away you would see a new life, a thousand times more powerful and bustling than our own; a big city like Naples would keep coming to mind [mne vse mechtalos ], all palaces, noise, thunder, life (8:51).

${ }^{14}$ Miller, Dosioevsky and The Idiot, 59. 
Myshkin's restlessness, unlike Nekhliudov's, was solitary. It fueled an expansive and compulsive need (of which the underground man speaks [5:118]) to pursue goals. These were not necessarily moral: the life Prince Myshkin hoped to discover beyond the horizon was "more powerful and bustling," not necessarily more virtuous than our own. It is natural, as Myshkin tells the village children in a draft of the novel, to want to discover new worlds, to want to be Columbus $(9: 242)$. According to this view, nature within us is dynamic but morally neutral. Moreover, something natural compelled Myshkin out of nature into civilization and city life. ${ }^{15}$ It may be natural for man to leave nature behind. This was the opinion of Alexander Herzen in his Letters on the Study of Nature, a work that Dostoevsky valued highly. ${ }^{16}$

Even in Lucerne, at the peak of his own Rousseauist fervor, Tolstoy does not claim that natural vitality itself is moral: as every mother knows, tickling and pinching are ambiguous behaviors. The morality of nature is suggested rather by the harmonious landscape with its "endless intermingling and variety of shades and lines, and over it all ... tranquillity, softness, unity, and the inevitability of the beautiful." Every particular thing has its proper place so as not to disrupt the beauty of the whole: in this sense natural harmony resembles morality understood as moderation. Myshkin, unlike Nekhliudov, at first found the Swiss landscape "oppressive" (tiazhelo). The very harmony of the setting, that which joins its constituent parts and gives shape to natural energy, weighed on his spirits. Later, however, Myshkin entered into nature's rhythms and lived in the present as the days seemed to grow longer. As he admits to the Epanchins, in him (unlike Nekhliudov) harmony and motion are in tension, but he claims to prefer the former while acknowledging the validity of the latter as well as its presence in himself. The passionate Aglaia scorns the prince's "quietism" (kvietizm), but he considers it better to live moderated by natural necessity, as if one were going to die tomorrow (8:53). In this he resembles Tolstoy. The Tolstoy who wrote Lucerne, Three Deaths (1859), Family Happiness (1859), Polikushka (1863), and even The Cossacks (1863) also preached "quietism," as was pointed out by Dostoevsky's friend and collaborator Apollon Grigoriev. ${ }^{17}$

Whether or not Dostoevsky was thinking of Lucerne when he wrote the Swiss part of The Idiot, a comparison between the two is enlightening. Drawing on the Naturphilosophie that helped shape Russian culture in the 1830s and 1840s, Dostoevsky, like Tolstoy, saw a parallel between human reason and natural necessity on the one hand, and human feeling and the forces of nature that bring about change and growth on the other. Like birds, we each sing our own song: bird imagery is used as a symbol of natural self-love in The Idiot. In nature necessity restrains the naturally weak self-love of individuals, imposing a harmony that becomes a model for the harmony of the soul. At this point, however, a crucial

\footnotetext{
${ }^{15} \mathrm{Joseph}$ Frank points to the idealism inherent in the prince's "transcendent yearning" to go beyond the division between sky and earth (Dosloevshy: The Miraculous Years, 1865-187/ [Princeton, 1995], 320). This idealism, I shall argue, is something unnatural in the prince, something that takes him out of nature.

${ }^{16} \mathrm{~A}$. Gertsen, Pis 'ma ob izuchenii prirody (Moscow, 1946), 19. Herzen agrees with Rousseau about the artificiality of contemporary civilization, but takes exception to his return to nature. He argues that to go backwards is itself unnatural (neeslestvemmy), and he sees a parallel between historical development and the natural development of organisms.

${ }^{17}$ See the two-part assessment of Tolstoy, "Graf Tolstoi i ego Sochineniia," published in nos. 1 and 2 of the Dostoevsky brothers' journal Vremia in 1862.
} 
difference between the Dostoevskian and Tolstoyan perspectives manifests itself. For the early Tolstoy, man is naturally moderate, not because be is reasonable, but because his desires naturally do not exceed his means to satisfy them. As natural beings we want both to be and to remain ourselves, free of anything external or internal that might restrain us or make us less ourselves. For Dostoevsky, by contrast, man is by nature a striving being, for whom freedom means not only self-preservation and self-expression, but expansion: "The need to declare oneself, to distinguish oneself, to stand out from the crowd is a law of nature for every human personality; it is his right, his essence, the law of his being." 18

Our striving is the natural consequence of our vitality. Restless human beings have left the state of nature behind. All parts of the soul, including reason, have expanded. A developed reason has brought about self-consciousness, which separates individuals from nature and from each other into "human personalities," lichnosti. Without reason, neither the personality nor passions could exist because we could not experience ourselves as distinct from other beings. Reason also fosters memory and forethought, so that time comes into being and self-consciousness unites the human personality over time. The individual no longer floats in an eternal present, moved by impulse and guided and restrained by necessity. The development of reason does not make man reasonable, however. Freed from the laws of nature, expanded into past and future, feelings develop into passions that disrupt harmony in society and in the individual. These passions both arise from and focus natural restlessness. They turn natural dynamism into willed goals, often evil ones. The prince's initial solution to the problem of corrupt civilization brought about by overweening passions, like Tolstoy's and Rousseau's, is a return to an eternal present and the state of harmony found in nature. Moderation founded on reason and conscience will affect this return. For Dostoevsky, however, the human personality, once formed, will not willingly subject itself again to natural necessity. Hence the oppressiveness Myshkin feels in Switzerland. The striving personality, even in someone as modest as he, cannot fulfil itself within external bounds imposed by nature.

In Tolstoy, knowledge of death moderates the individual. Daddy Eroshka in The Cossacks and Uncle in War and Peace speak for Tolstoy when they eschew sin because they know they will die. While the "quietistic" Myshkin, linking moderation and mortality in his first conversation with the Epanchins, may implicitly echo this position, the dying Ippolit takes the opposite tack. He rebels against any morality based on natural necessity. For him, nature's automatic sacrifice of the individual to the whole is inherently unjust and immoral. To the striving personality, nature promises only unnatural restraint in the first place, and inevitable annihilation in the end. If we do live "naturally," moreover, we follow an external code of morality and forfeit our freedom to choose, and therefore our status as moral beings. In Dostoevsky's view, natural harmony in human life, however reasonable it may seem, once destroyed cannot and even ought not be restored. Here the crucial text for him would have been Friedrich Schiller's On Naive and Sentimental Poetry. He would have identified, like Schiller himself, with the sentimental

\footnotetext{
${ }^{18}$ From Dostoevsky's 1861 "Introduction" to a "Series of Articles on Russian Literature" (18:68; emphasis added).
} 
poet, striving in freedom for morality; while Tolstoy, like Goethe in Schiller's scheme, would represent the naive, epic personality.

To do full justice to Tolstoy's version of natural morality while presenting Dostoevsky's critique of it, we must note the limits of that morality as Tolstoy himself understood it. Both Daddy Eroshka and Uncle-characters whom Dostoevsky never discusses-are warriors who, having been moderated by war and old age, continue to live a full life in the present. Both are former soldiers who no longer pursue glory, but neither denies himself anything else that a man might want, including wine, women, and song. In these characters Tolstoy restores the childish balance between happiness and goodness without sacrificing one for the other. Through them he calls upon us to relinquish pride, including its most fundamental manifestation, that desire to distinguish ourselves that Dostoevsky calls a law of nature. We must agree to live the life of the body. For Dostoevsky this is humanly impossible. He sets a higher standard for virtue, one that Tolstoy too would agree could not be met in a simply natural life. But, as Dostoevsky explains in Winter Notes on Summer Impressions, that standard itself is grounded in human nature.

Let me be understood: the free, completely conscious sacrifice of the self for the good of all, not coerced by anyone, is in my opinion a sign of the highest development of the human personality, of its greatest power, its greatest self-control, the greatest freedom of one's own will.... This is a law of nature, it is normal for a human being to be drawn to this. (5:79; emphasis added)

Things are not quite as they seem at first in Tolstoy and Dostoevsky. Tolstoy's return to nature requires the sacrifice of pride, hence of the desire to distinguish ourselves, in the name of moderation. The moment of moral choice occurs when we choose to limit ourselves for our own happiness and for the sake of the harmony of the whole. Tolstoy does not deny the difficulty of moderation and even its impossibility in passionate youth-in The Cossacks both Olenin and Lukashka attest to this - but he still singles it out as a moral goal attainable in old age. Dostoevsky calls for a more exalted goal, self-sacrifice, which, however, turns out to be psychologically the greatest expression of the self, and therefore of pride. Dostoevsky is aware of this drawback to his initial solution to the problem of freedom and morality. He goes on to say that even a trace of calculation or self-interest invalidates self-sacrifice (5:79-80); to avoid this contamination, self-sacrifice must be an instinct derived from culture, rather than a conscious decision. For Dostoevsky, pride of self is natural; therefore, no self-conscious human being can give it up to live a purely animal life. For Tolstoy, self-sacrifice, psychologically an expression of pride, cannot be truly virtuous.

Tolstoy recommends a real humbling of the self which can only be accomplished when reason dominates the passions. Dostoevsky does not believe in such moderation. No character like Uncle, who serves informally as a judge in the community while enjoying all the pleasures of the flesh, ever appears in a Dostoevsky novel. In Dostoevsky's opinion, Tolstoy and others like him underestimate the power and primacy of human vitality over reason. Myshkin's Tolstoyan/Rousseauian understanding of nature does not sufficiently account for the power of the "unbridled sensuality, the craving for power, and 
possessiveness (the acquisitive instinct)" which Robert Jackson identifies as the "locus for evil" for Dostoevsky. ${ }^{19}$ These are the effects of naturally expansive self-love, freed from nature but unleavened by higher spiritual goals. In The Idiot, Rogozhin, who has no Tolstoyan associations whatsoever, reveals the potential inhumanity of human nature. With his high forehead and brutish "undeveloped" lower face he combines raw intelligence with animal spirits. ${ }^{20} \mathrm{He}$ represents natural man one step beyond nature, pursuing a goal-Nastasia Filippovna - to whom he denies any spiritual value. His obsession with Nastasia Filippovna imprisons him in the present time of pure impulse, in which, according to the envious Ippolit, he lives a full "unmediated" life (8:337). In this state, he feels no repentance even after his attempted murder of the prince (8:302). This is especially alarming to Myshkin, who knows that the conscience works better after the fact, once passion has cooled. But Rogozhin declines to be reasonable and just. Until the spell that Nastasia Filippovna has cast over him is broken by her death, Myshkin, who may temporarily arouse him from his moral slumber, cannot really penetrate Rogozhin's insect-like egoism. The two are indeed doubles, as George Steiner has perceived, with each representing a potentiality of the "human personality," the one for perfect selfishness, the other for morality. ${ }^{21}$ This bifurcation as human beings depart from the state of nature generates the double thoughts that Myshkin observes in many of the characters in the novel as well as in himself, and hence one condition necessary for moral choice..$^{22}$

Despite all this, Dostoevsky loves Myshkin and his idealism dearly. The more Dostoevsky insists on the freedom of the human personality from natural necessity, the more pressing becomes the question of what, if not nature, would make a human personality good. What in human nature, besides an expansive self-love and a natural reason too weak to control this love, could provide goals for human life? Just like Tolstoy, Dostoevsky was convinced that moral goals, or ideals as he called them, were crucial for morality.

\section{WAR AND PEACE}

At the beginning of The Idiot, Dostoevsky questions the viability of a Rousseauian return to nature, and he associates Tolstoy with this failed Rousseauist solution to the ills of civilization. Reading Tolstoy this way, he concurs with such contemporaries as Turgenev, who called Lucerne "a mixture of Rousseau, Thackeray, and the short form of the Orthodox Catechism."23 Later in the writing of the novel Dostoevsky seems to refer to Tolstoy

\footnotetext{
${ }^{19}$ Sec Jackson, The Art of Dostoevsky, 9, 82, 240.

${ }^{20} \mathrm{~A}$. L. Volynskii remarks on Rogozhin's exceptional intelligence. See his Dostoevskï (St. Petersburg, 1906), 67.

${ }^{21}$ George Steiner, Tolstoy or Dostoevsky: An Essay in the Old Crificism (New York, 1959), 151-52.

${ }^{22}$ If both Myshkin and Rogozhin are open to the experiences of their double-Myshkin to evil thoughts, Rogozhin to good ones - this is because they function in the novel both as representatives of parts of the human personality, and as full human beings, who have both good and bad impulses.

${ }^{23}$ Quoted in N. N. Gusev, Lev Nikolaevich Tolstoi: Materialy k biografii s 1855 po 1869 god (Moscow, 1957), 224. Whether he knew it or not, Dostoevsky's own vision of the expansive self, like the Tolstoyan concern with unity of self, may be traced back to Rousseauian metaphysics and psychology. See Arthur Melzer, The Natural Goodness of Man: On the System of Rousseau's Thought (Chicago, 1990), 44-45.
} 
again in the very different context of his own response to the necessity of ideals or laws beyond those set by the individual. Again he both borrows from his rival and pushes off from what he perceives as a wrong-headed solution to a rightly perceived dilemma. It is impossible and really irrelevant in this case to say exactly when Dostoevsky turns from Tolstoy to concentrate on his own issues. The specific details of influence matter less than the movement - smooth and yet totally metamorphosing--of material from Tolstoyan to Dostoevskian territory. Only material of extraordinary relevance to both writers could move so fluidly and so completely from one to the other.

Tolstoy resumed publication of his novel in December 1867, when half of it came out in book form and under the title War and Peace. The Academy editors suggest that Dostoevsky already knew it by 1 March 1868 (new style), when he wrote his friend A. N. Maikov from Geneva that he had read the first half of the novel and considered it a "most important thing" (9:465). On 1 April, Dostoevsky included in his notebook, in a list of themes clustered around the personality of Prince Myshkin, the words "CHAIN AND HOPE" (TSEP'I NADEZHDA; 9:241). The next item on the list is "TO DO A LITTLE" (SDELAT'NEMNOGO). The word "chain" appears twice more, both times in an entry dated 24 May $(9: 269,270)$. The editors of the Academy edition conjecture that this "chain" may allude to Pierre's speech to Prince Andrei, in the scene at the ford which indeed appears in the first half of War and Peace. Pierre speaks of a great ladder, or chain of being, that connects all living things, and the Academy editors go on to speculate that this chain may be one origin of Father Zosima's idea of the connection of all things.

The hard evidence adduced by the editors to prove their case is skimpy, and suspect because in the letter to Maikov by "the first half of the novel" Dostoevsky may mean 1805. This is made more likely by his complaint that the novel contains "too many trivial psychological details, there could be a bit fewer" (28.2:258-59). When he revised it for inclusion in War and Peace in 1867, Tolstoy in fact shortened 1805 substantially, ridding it of many "psychological details." In the same letter Dostoevsky also tells Maikov that he has read a plot summary of the 1867 War and Peace published in Russkii vestnik, and it may be in this context that he alludes to what he has personally read-1805-as half the novel. On the other hand, we can be sure that Dostoevsky got his hands on Tolstoy's "most important" publication as soon as possible. Most compellingly, both in the diary and later in the novel itself the idea of the chain develops in ways that hint of its Tolstoyan beginnings.

Although Pierre does not actually use the word "chain" in his speech to Andrei, he does refer to himself as "one link [zveno], one step from the lower beings to the higher." If a ladder from lower to higher exists, he tells Andrei, then "there is truth, there is virtue." The two friends are discussing whether there is any basis for altruism, doing good for others for its own sake. Pierre, enthralled by noble Masonic ideals of helping others, fails to put them into practice; while Andrei, perversely denying that he could or would be doing good for others, efficiently improves his estate and the lives of his serfs. Listening to Pierre talk about a chain, or ladder of being, which Andrei identifies with the philosophy of Herder, he feels hope for virtue revive in him-hence the cryptic "chain and hope" 
in Dostoevsky's notebook. ${ }^{24}$ Dostoevsky himself subsequently switches in the notebook from chain (tsep) to link (zveno). Two lines down from the third and last repetition of the word "chain" he writes, "To ring like a link. To do a little" (Zvuchat'zvenom. Sdelat' nemnogo).

Entering The Idiot, Pierre's image takes on Dostoevskian form and function while retaining traces of its origin. Dostoevsky gives its direct expression in the novel not to Myshkin (as he had to the prince in the notebooks), but, as the Academy editors note, to Ippolit, in his monologue about the good influence of a single deed. Ippolit is recalling an experience in his own life which seems to echo the meeting of Pierre and Andrei at the ford. He sets the scene in one brief sentence that conjures up the expansive lyricism of the episode in War and Peace. "It was the beginning of May, the evening was clear, the huge ball of the sun was sinking into the bay." Just as in War and Peace the scene takes place on a clear evening in early May, at sunset, and by water. At the same time, the images of sunset and water highlighted by Dostoevsky are part of his own system of spiritually charged metaphors. ${ }^{25}$ Ippolit and his friend Bakhmutov stop to talk on the Nikolaevskii Bridge, and gaze down into the water, as Andrei and Pierre do at the ford. Enthusiastic and kind, the gentlemanly Bakhmutov is like Pierre, whose last name, Bezukhov, moreover, sounds somewhat like Bakhmutov. Ippolit resembles Andrei: both are harsh and proud with a hidden, childlike vulnerability, both are sickly, and both are immensely concerned with obtaining the approval and love of others. In Andrei this translates into a love of glory which he defines before the battle of Austerlitz as a desire that others love him; but whereas Andrei wants to win the love of others by being a great general, Ippolit, as a philanthropist and intellectual, wants to obtain the love of others through good deeds.

In War and Peace, Pierre finally moves his friend, who looks at him "with a luminous, childlike, tender gaze" and recalls the sky at Austerlitz when he had had his first intimation of immortality. Bakhmutov has no such effect on Ippolit. In notes to his later novel, The Adolescent, from March 1875, Dostoevsky describes Prince Andrei as a "poorly educated" "representative of banal self-love" who "reforms" (ispravliaetsia) because of the "good example" of Pierre Bezukhov (16:329). (Although the "reformation" to which

\footnotetext{
${ }^{24}$ Patricia Carden traces Tolstoy's knowledge of Herder to an article in an issue of Ves/nik Evropy' (no. 14, 1804) that was in the Iasnaia Poliana library. For her excellent discussion of Tolstoy and Herder see "The Expressive Self in War and Peace," Canadian-American Slavic Sludies 12 (Winter 1978): 526-28. Book 5, chapter 6 ("The present State of Man is probably the connecting Link of two Worlds") of Herder's Oullines of a Philosophy of the History of Man [Ideen zu einer Philosophie der Geschichte der Menschheit (1784-91)] begins with the following declaration: "Everything in Nature is connected; one state pushes forward and prepares another. If then man be the last and highest link, closing the chain of the terrestrial organization, he must begin the chain of a higher order of creatures as its lowest link, and is probably, therefore, the middle ring between two adjoining systems of the creation. ... This view of things, which is supported by all the laws of Nature, alone gives us the key to the wonderful phenomenon of man" (the translation is by T. Churchill [London, 1800]). See also book 5, chapter 1, for Herder's explanation of the organization of nature according to the great Chain of Bcing. Arthur O. Lovejoy, The Greal Chain of Being, A Sludy of the History of an Idea (Cambridge, MA, 1942), has traced this idea back through Western culture and the Neo-Platonists to Plato himself, and hence to those very Platonic ideas that are present in other forms in War and Peace.

${ }^{25}$ In Crime and Punishment, Raskolnikov feels a brief respite from his obsessive plans to commit murder when he crosses a bridge of the Neva at sunset and looks down into the water $(6: 50)$. On the sun and particularly on sunsets in Dostoevsky see Knapp, The Annihilation of Inerfia, 131-32, 160, 164, 180.
} 
Dostoevsky refers later in this note takes place when Andrei witnesses the amputation of Anatole's leg, it is only at the ford that Pierre is shown actually to influence his friend [16:330].) In place of Prince Andrei and other literary heroes like him, Dostoevsky goes on in his notes to proudly trumpet his creation of the tragic figure of the underground man, who knows the good but cannot do it because he does not believe in "general laws. [For him] nothing is sacred' (16:330). Ippolit is just such an underground man. In an exquisitely ironic twist to The Idiot that anticipates this later illusion to War and Peace, Dostoevsky has Ippolit (standing in for Andrei), deliver his version of Tolstoyan idealism to Bakhmutov (Bezukhov), rather than the other way around. Ippolit, like Andrei when Pierre visits him on his estate, is no Herderian idealist. As a modern man, Ippolit believes in a mechanical nature, the logic of which precludes freedom and virtue. Andrei will eventually rediscover higher reason in nature; but for Ippolit, his own good impulses cannot be natural because if they were, true moral freedom would not be possible. As purely natural beings, we could no more freely chose virtue, and therefore truly distinguish ourselves, than we could as cogs in a machine. ${ }^{26}$ Yet Dostoevsky agrees with Pierre and Tolstoy that goodness truly does exist. Just as with the underground man, the proof of this in The Idiot is Ippolit's preoccupation with goodness and love in spite of his theories.

Although Ippolit contradicts his own theories of egotism, he does not attribute his desire to do good to natural law. Already in the notebook to The Idiot, the link (zveno) of a single good deed appears as a free agent that acts of its own accord, a link that "rings" as it "does a little." There is no mention of any chain of being that morally structures the natural world. In the novel a new chain forms, made up of free acts that wind strands of goodness through human life. This idea resonates throughout The Idiot, but is expressed directly only by Ippolit in his conversation on the bridge with Bakhmutov (8:325-26).

Ippolit depicts his good deeds not as links, but as seeds cast into the world to sprout future consequences. Moving from the notebooks to the novel, Dostoevsky substitutes a metaphor of growth for one of structure. ${ }^{27}$ He thereby emphasizes again that whatever we do must be the result of some passion or feeling. Although natural vitality itself is morally neutral, it is necessary to positive acts of goodness because it fuels all activity, good and bad. In Myshkin it fuels those impulsive acts of goodness, starting with his befriending of Marie in the Swiss village and continuing with his various interventions in Russia, that have both good and bad consequences in the novel. The prince, it will be observed, is not really a "quietist." His desire to do as opposed to be good is the product of his own particular vitality, that natural "restlessness," so disruptive of order, that overwhelms his reason from time to time even in Switzerland.

For Dostoevsky, morality, as opposed to unfocused vitality, is a purely human possibility that comes into being only after human beings have left the state of nature. Moral structures are built by men, not imposed on them by any law inherent on the external world. As A. P. Skaftymov has so perceptively argued, what separates Myshkin from

\footnotetext{
${ }^{26}$ See Knapp's discussion of natural man according to Dostoevsky (ibid., 23-24).

${ }^{27}$ The seed metaphor is highly developed in The Brothers Karamazov, where Dostoevsky preserves the notion of a chain as well. As Miller observes, "the chain as a symbol of the immortality of good deeds" is "crucial" in The Brothers Karamazov (Dostoevsky and The Idiot, 59). Note again, bowever, that the chain in that novel refers to human deeds rather than a structure in nature.
} 
lppolit (as well as from many other characters) is his humility as opposed to Ippolit's pride $^{28}$ In Dostoevsky as in Tolstoy, pride and compassion (sostradanie) are linked as emanations of the rational part of personality. Pride is the "rational" passion, not because it is itself rational, of course, but because, like compassion, it depends upon our ability to compare ourselves with others. Comparing ourselves to others through the faculty of reason, we can both isolate ourselves through pride and identify with others through compassion. Myshkin has a uniquely, even unnaturally weak self-love. He is, in Ippolit's words, a Human Being (Chelovek) pure and simple rather than a particular individual (8:348). Because he lacks pride, Myshkin is able to enter into an equal relationship with the Swiss children and to influence many of the impossibly proud and wounded characters whom he meets.

Myshkin's characteristic passion is compassion instead of pride. At a crucial moment in the novel, just before Rogozhin tries to stab him, Myshkin argues with himself that the single law of humanity must be compassion (8:192). Both in this instance and in the bloody denouement of the novel, compassion proves defenseless against Rogozhin's obsession, but this does not mean that compassion is simply impotent in human life. Myshkin cannot resist it. Rogozhin chooses egoism, but even in him the potential for altruistic love remains. What nature cannot explain is why anyone would choose one potentiality allowed by reason - compassion - over the other-pride. Nature can account for the self-love that motivates pride, but not for the love of others that is part of compassion. ${ }^{29}$

The source of pure love of others, according to his own version of Platonic theory that Dostoevsky unveils for the first time in The Idiot, is a "universal soul" with which Myshkin is in touch through his epilepsy. On the brink of each seizure he experiences "a feeling of fullness, measure, reconciliation, and ecstatic prayerful merging with the very highest synthesis of life" $(8: 188)$. The more isolated the "human personality," the stronger the desire to return to this universal soul, to join with others through a good deed. This would be the positive internal will parallel to the Herderian chain of being that would impart a moral goal to human striving. In Ippolit, with his desperate clinging to individual life as he feels himself slowly dying, this desire for the "joining (priobshchenie) of one personality to another" has an erotic intensity: "Casting your seed, casting your 'alms' (milostynitu), your good deed in whatever form, you are giving up part of your human personality (lichnost) and you are receiving in yourself part of another; you are mutually joining together one with another" $(8: 336)$.

\footnotetext{
${ }^{28}$ A. P. Skaftymov, "Tematicheskaia kompozitsiia romana Idiota," in Tvorcheskii put' Dostoevskogo: Sbornik statei, ed. N. L. Brodskii (Leningrad, 1924), 131-85. Myshkin's last name, derived from mysh ' "mouse") contrasts with his first name, Lev ("Iion"). The name Myshkin could be a joke, meant to distinguish Dostoevsky's moral man from Tolstoy's proud moral hero, Prince Dmitrii Nekhliudov, Nikolenka's friend in Adolescence and Youth, the hero of Morning of a Landowner, and the narrator of Luceme. But the mouse roars in Myshkin's strident speech at the Epanchins' party.

${ }^{29}$ As Nicholas Berdiaev discerned, compassion itself is natural and therefore a mixed emotion, with an clement of egoism in it (Dostoevsky [1934; reprint ed. New York, 1957], 127). Only Christian love is pure love of others.
} 
At the end of this speech, which continues for some time, Bakhmutov detects in Ippolit's face a desire to throw himself into the canal. Ippolit's "final decision" to commit suicide, leaving aside all his other complicated motives for it, including his declared frustration that he cannot spend his life doing good deeds, is born at this moment out of his erotic striving expressed in the desire to drown, to extinguish the isolated consciousness that causes him so much suffering. No wonder then that he speaks of suicide in the same language he has used for his good deeds. "But in that evening and that night was cast the first seed of my 'final decision' [to commit suicide]" (8:337).

The Idiot is akin to War and Peace in its concern for a metaphysical justification for ethical behavior. But whereas Tolstoy grounds moral law in natural harmony, making it prior to human history, Dostoevsky sees it as a goal to be achieved through human history, in the future. It must be in the future because true freedom, and hence the possibility of true morality, does not come into being until the formation of the "human personality" which is free of all natural constraints. Prince Andrei's human personality is fully realized only by his final resignation to natural law and the dignity it confers. In Dostoevskian terms, Prince Andrei moves back from the I (the particular individual) to the All by finally shedding his particularity altogether in death. ${ }^{30}$ This happens when reason and his extreme circumstances combine to give him an objective view of all lives, including his own. Dostoevsky's characters are not allowed to escape time and their necessary imperfection within time in the same way. As truly free beings, they vacillate between the selfsacrificing and egotistical poles of the human personality. They must discover again and again that they can choose good as well as evil. Nature is the source of healthy self-love. Love of others, which is of supernatural origin, provides the will to choose the other over the self without, however, mandating that choice.

In "Who Should Be Teaching Whom?" Tolstoy states that our goal lies in the past, that is, in a natural perfection or harmony in which we are born. In The Idiot Dostoevsky takes his characters back to nature, to the green bench in the great park at Pavlovsk, only to show that a return to nature neither makes us good nor fully explains human behavior. Earlier, out of love for his fellow man, Myshkin himself, wandering in the park, resists the temptation to escape "back where he had come from," back to nature in Switzerland, in search of his own happiness $(8: 256)$. Instead, he chooses to go forward because he already feels himself morally entangled in the thickets of Russian reality. This decision is made contrary to the prompting of his natural self-love. It makes him "completely unhappy," and it is expressed entirely in the convoluted negatives of moral duty.

To escape was impossible ... it would be practically cowardice ... before him loomed such tasks, not to resolve which, or not to use all his powers to try to resolve which, he now did not even have the right (Bezhat' nevozmozhno, chto eto budet pochti malodushie, chto pred nim stoiat takie zadachi, chto ne razreshit' ili po krainei mere ne upotrebit' vsekh sil k razreshenïu ikh on ne imeet teper' nikakogo dazhe i prava). (8:256; emphasis added)

${ }^{30}$ I refer to Dostoevsky's metaphysical reflections penned while sitting at the bier of his first wife in 1864 (20:172-75). 
The fountainhead of this contrary impulse is something entirely internal to the human soul, which flares up in Myshkin before his epileptic fits. Ippolit in turn is influenced morally not by his natural surroundings, but by other human beings, by a good man associated with Tolstoy, namely, Prince Myshkin. Everything that Ippolit describes in his confession, his "Urgent Explanation," takes place in the five months after he has heard of the prince from Kolia Ivolgin. During that period, without ever meeting Myshkin, Ippolit has been obsessed with him $(8: 249,322)$. For Dostoevsky, human perfection lies inside the soul, in history, and in the indefinite future, as an unattainable goal which, however, redeems human life. The ideal of a chain or ladder of being in nature that Dostoevsky originally associated with War and Peace is transformed in The Idiot into a potentiality of the "human personality" - to "ring like a link. ... To do a little"-which each individual may choose. Dostoevsky thus both preserves freedom and, just as importantly, provides a moral goal without compromising freedom.

Both Dostoevsky and Tolstoy are realists in their implicit acknowledgment of the primacy of psychological law over miracle in human behavior. Both expand the boundaries of human psychology with their insistance of the psychological need of the individual to be accounted good by himself and others. Dostoevsky's psychology is more radical than Tolstoy's in its rejection of the power of reason over man. He also sets his sights higher than Tolstoy in War and Peace, on a morality that requires true self-sacrifice within life: only this, he believes, will validate the self and free it from overweening passion. Tolstoy calls for a moderation of the self that may or may not be psychologically possible, but does posit the psychologically desirable goal of a reconciliation of happiness and virtue; while Dostoevsky calls for self-affirmation in a sacrifice of natural happiness that he believes is impossible except through Christian love. This self-sacrifice, however, would have the morally incidental but psychologically crucial consequence of truly satisfying the demands of pride. 